Publisher: Taylor \& Francis

Journal: Expert Review of Anti-infective Therapy

DOI: $10.1080 / 14787210.2016 .1206468$

\title{
Antibiotic use in acute respiratory infections in under-fives in Uganda: findings
} and implications

\author{
Kibuule Dan ${ }^{1}$, Kagoya Harriet Rachel ${ }^{2}$ and Brian Godman ${ }^{3}$
}

${ }^{1}$ School of Pharmacy, Faculty of Health Sciences, University of Namibia

Box 13301, 340 Mandume Ndemufayo Avenue Pioneers park, Windhoek, Namibia

\section{Corresponding author*}

Kibuule Dan*, B.Pharm (Hons); Msc. Clinical Pharmacology

Head of Department Pharmacy Practice and Policy/Senior Lecturer

E-mail: dkibuule@unam.na ,Cell: +264 (0) 81-628 0835

Role: Co-investigator, conceptualization, data analysis and write up

${ }^{2}$ Management Sciences for Health -Namibia

Box 90027 Klein Windhoek, 31 Feld Street Ausspannplatz, Windhoek Namibia

Kagoya Harriet Rachel; Masters of Public health; MBA-Project management

E-mail: kharrietrachel@yahoo.com; Mobile: +264 816873619

School of Public; Faculty of Health Sciences Makerere University Kampala

Role: Principal investigator, data collection, conceptualization, and write up

${ }^{3}$ Strathclyde Institute of Pharmacy and Biomedical Sciences, Pharmacy, United Kingdom

141 Cathedral Street, Glasgow, G4 ORE, UK

Godman Brian; PhD, Professor of Pharmacoepidemiology and Division of Clinical Pharmacology,

Karolinska Institute, Stockholm, Sweden

E-mail: brian.godman@strath.ac.uk

Strathclyde Institute of Pharmacy and Biomedical Sciences

Role: Manuscript conceptualization, write up and editing 


\section{ABSTRACT}

Objectives: Self-medication with antibiotics among households is common in Uganda. However, there are limited studies evaluating self-purchasing of antibiotics for acute respiratory infections (ARI) in the under-fives. Consequently, the objective was to evaluate patterns of household self-medication with antibiotics in ARI among under-fives in Kampala.

Methods: Descriptive cross-sectional observational design. Care takers at households were selected from five divisions of Kampala using the WHO 30-cluster method and interviewed using a standardized questionnaire in June - July 2011.

Results: Out of the 200 households, most ARI cases 107 (53.5\%; $p=0.322$ ) were inappropriately managed. The prevalence of antibiotic use in ARI was $43 \%(p<0.001)$. Amoxicillin $31.4 \%$ and cotrimoxazole $(30 \%)$ were the most self-medicated antibiotics. Antibiotics use was associated with pneumonia symptoms and access to antibiotics.

Conclusions: Household use of antibiotics in ARIs among under-fives is suboptimal. There is an urgent need for guidelines on awareness to reduce self-medication of ARIs in Uganda.

KEY WORDS: Acute respiratory infections (ARI), antibiotics, under-fives, households, selfmedication, Uganda 


\section{INTRODUCTION}

Acute respiratory infections (ARI) are a leading cause of mortality among the under-fives: with over 2 million children dying each year from ARI in sub-Saharan Africa [1-3]. In Uganda, the burden of $A R I$ among under-fives is estimated at $18.3 \%$ with community acquired pneumonia accounting for $33 \%$ deaths from an ARI [4-6]. ARIs among under-fives are a major driver for the use of antibiotics among households and health facilities $[7,8]$. This is a concern if inappropriate use increases antibiotic resistance and hence increases morbidity, mortality and cost of treatment [9 - 12]

Inequitable access by households to medical insurance and essential medicines including antibiotics remains a major bottleneck to public health in sub-Saharan Africa [13 -19], with impoverished households being the most disadvantaged to accessing quality healthcare [20 22]. This is made worse with increasing antibiotic resistance necessitating the use of newer antibiotics which are typically more specific and more targeted; however, are more expensive and with a higher level of adverse effects [12]. Indiscriminate self-purchasing of antibiotics can make the situation worse with over $50 \%$ of antibiotics used worldwide obtained without a medical prescription [23]. This is made worse in Uganda with most households having little confidence in the public health care system $[\mathbf{1 3}, \mathbf{2 4}, \mathbf{2 5}]$. This is illustrated in Uganda by only $38 \%$ of mothers of under-fives engaging the public health care sector [17] with self-purchasing of antibiotics a common household practice in urban and rural Uganda [26 - 34]. Informal drug outlets in Kampala, a porous medicine supply chain and poor regulation further exacerbate household self-purchasing of antibiotics $[29,31]$.

Despite published studies demonstrating that household interventions have successfully reduced the burden of malaria in Uganda; the overlap of symptoms of ARI, malaria, fever and malaise propagates irrational antibiotic use $[19,22,30,35,36]$. As mentioned, this indiscriminate use of antibiotics is the main cause of antibiotic resistance and poor treatment outcomes is made worse in low and middle income countries by limited access to full antibiotic courses [7, 18, 35, 37-40]. Little is known about self-purchasing of antibiotics among households with young children in Uganda, which is a key target area for appropriately managing ARI. Consequently, the aim of this study was to investigate the prevalence and patterns of self-purchasing of antibiotics among households with young children in Kampala, the capital city of Uganda. The household level was chosen to provide a more accurate picture of current behaviours and their rationale rather than trying to interview family members in pharmacies where maybe less time for such surveys and confidentiality may be an issue especially in crowded pharmacies The findings potentially used to suggest future interventions to all key stakeholders to improve the appropriate use of antibiotics.

\section{MATERIALS AND METHODS}

\subsection{Design, setting and study population}


We adopted a cross-sectional survey design to collect qualitative and quantitative data using a standardized questionnaire (Appendix A). A sample of 200 households was estimated using the Kish and Leslie formula (1965) [41].

The 200 households from the five divisions of Kampala city including Nakawa, Kampala central, Makindye, Kawempe and Rubaga were selected using the World Health Organization (WHO)-30 cluster method [42]. Care takers were included in the study if they had at least one child under the age of five years and gave informed consent for inclusion in the study. Care takers for the selected households were briefed on the study and only those that gave a written consent were interviewed by a team of five trained data collectors using a pre-tested and standardized questionnaire.

The questionnaire contained questions regarding: household sociodemographic characteristics, occurrence of the ARI in the past 4 weeks, type of ARI episode; antibiotic use for management of the ARI based on the WHO ATC/DDD classification; the treatment seeking behaviour and outcomes for the most recent ARI episode.

This study was conducted from the 11-June-2011 to $10-J u l y-2011$, a period that coincides with the peak of ARI in Uganda [43].

\subsection{Methods}

The sampling frame was based on household distribution in the Uganda Demographic and Health survey 2000 (UDHS, 2000). To assess for occurrence of ARI, we asked whether any of the children under-five had symptoms of common cold, cough, throat infection, or ear infection or pneumonia in the past four weeks. The local terms for; cough "kifuba, lubyamira", and common cold "eminyila" were used. The nature of ARI was further investigated for by the data collectors. The main outcome variables of the study were; period prevalence of ARI; prevalence and patterns of antibiotic self-prescribing and factors associated with antibiotic self-purchase. We interviewed respondents on their perceived confidence to self-diagnose ARIs. Data were managed using Epidata v3.1 and exported to SPSSv21 for quantitative analysis. Group comparisons were made using chi-square and $\alpha=0.05$ was considered as the level for denoting significance at the $95 \%$ confidence interval. Univariate and bivariate analysis was done using the Chi-square test $\left(\chi^{2}\right)$ for associations and the Pearson correlation was used to identify factors associated with appropriate management of the ARI. The appropriateness of treatment for the each ARI episode was evaluated against recommendations of the integrated management of childhood illnesses (Table 1) [44].

\subsection{Ethical considerations}

The study was registered as field study for Masters in Public Health of by the school of public health, Makerere University, Uganda. This included ethical approval. All the study respondents gave written informed consent prior to inclusion in the study. The respondents names were not requested or recorded anywhere hence we cannot associate the data to a particular 
respondent in this study. No personally identifiable data such as names were requested or recorded.

\section{RESULTS}

\subsection{Social demographic characteristics of respondents at the households}

The survey completion rate was $99.5 \%$ (199/200). One questionnaire was excluded due to incomplete data on age of a child at one household. Most household respondents were mothers (46.2\%); lived in semi-urban settlements (45.5\%); and attained at least secondary education (68\%). The difference in the male and female respondents was not significant $(p=$ 0.258) (Table 2).

\subsection{Period prevalence of ARI among household with under-fives in Kampala-Uganda}

Respiratory tract infections (RTIs) commonly occur among under-fives in households in Kampala-Uganda. The common cold (99.5\%) and coughs (81.9\%) are the most prevalent upper respiratory tract infections among households with under-fives who had an ARI during the past 4 weeks. Pneumonia (9\%) was the most occurring lower respiratory tract infection (Figure 1).

\subsection{Patterns of self-medication with antibiotics for ARI among household with under-fives}

The period prevalence of antibiotic use for ARI in under-fives at households in Kampala-Uganda was $43 \%$ (86/199) households. Out of the 86 households that self-prescribed, purchased and used an antibiotic, a quarter $26 \%(22 / 86)$ used at least two antibiotic medicines (Figure 2). Penicillins (43\%) and sulphonamides (40\%) were the most self-prescribed classes of antibiotics for treating ARIs among the under-fives at households in Kampala (Figure 3).

Most households that self-prescribed antibiotics for ARI for under-fives used mono therapy with either Amoxicillin (ATC J01 C) or Cotrimoxazole (ATC J01E) or two antibiotics were taken together that had a combination with penicillins (ATC J01R). Most households that selfprescribed dual antibiotic regimens for the children under 5 also used a combination of amoxicillin and cotrimoxazole $19 \%(16 / 85)$. Some households also used antibiotics with safety concerns in children including gentamicin $3.5 \%(3 / 85)$ and chloramphenicol $2 \%(2 / 85)$ (Figure 
A1 in the Appendix). Whilst most households used oral antibiotics, there was also parenteral use.

Antibiotics were mostly used for common colds among young children when taken $41.9 \%$ (13/31) with 18/ 31 young children no taking antibiotics; common colds with coughs $45.5 \%$ (40/88); common cold, sinusitis and cough 61\% (11/18); common cold, cough and throat infection $50 \%(9 / 18)$ and common cold cough with sinusitis and pneumonia at $100 \%$ for both children with this combination of symptoms (Figure A2).

\subsection{Factors associated with the use of self-prescribed antibiotics}

The use of self-prescribed antibiotics in the management of ARI among households with underfives was significantly $(p<0.05)$ associated with the location of the household; level of education of the guardian / parents; confidence to self-diagnose ARIs; treatment seeking behaviour; source or access to antibiotics and the prior ability to treat ARI appropriately (Table $3)$.

\section{DISCCUSION}

Our study has shown that over two out of every five households in Kampala-Uganda (43\%) selfprescribe antibiotics for ARI episodes among under-fives (Figure 2). Some households use two antibiotics, parenteral forms and contraindicated antibiotics for ARIs in under-fives (Figures 2 \& Figure 4). Our findings are similar to other studies among developing countries, which estimated self-medication with antibiotics between 8- 87 of patients [17]. A systematic review of 36 studies reports a similar prevalence of $38.8 \%$ to that of our findings of self-medication among households and $50 \%$ prevalence for respiratory infections [45]. Household surveys in Trinidad and Tobago [46] and Sudan [3] also reported higher rates of 68\% (288/450) and 73.9\% respectively of self-medication. However, a study in Indonesia found a lower period prevalence of self-medication with antibiotics (7.3\%) [47]. The majority of these studies though whilst they assessed antibiotic use in households, this was not specific to under-fives and/ or acute RTIs. In addition, a number were conducted in rural settings where the use of left-over antibiotics is more common [28].

The common cold and or cough were the most common ARIs among the under-fives at households in Kampala, with the period prevalence for pneumonia symptoms at 9\% (Figure 1). Similarly surveys in Uganda $[5,6,28]$ and sub-Saharan countries [34] have also reported a high 
burden of ARI at households and public health facilities. Studies in Kenya have associated the high prevalence of ARI (69.7\%) among the under-fives as a driver for household overuse of antibiotics [48]. High rates of self-purchasing are exacerbated if there is a belief among households that antibiotics can cure any illness as seen for instance with household surveys in China [22] and Trinidad and Tobago [46].

Amoxicillin (ATC J01C) and or cotrimoxazole (ATC J01E) alone or in combination are the most self-prescribed (86\%) ATC classes of antibiotics for ARI at households in Kampala-Uganda (Figure A1). Studies conducted in Indonesia, Kenya and Sudan have also reported selfprescribing of penicillins among households [46-49], cotrimoxazole [46] and macrolides. This is perhaps not surprising as these classes of antibiotics are the most recommended for the management of ARI among guidelines when an antibiotic is indicated $[50,51]$. They are also inexpensive, commonly prescribed by clinicians and can easily be recognized by their colors; in addition, the most accessible left-over medicines at households and drug outlets $[\mathbf{2 8}, \mathbf{2 9}, \mathbf{3 1}$, 45].

Other studies have also reported high rates of self-prescribing with broad spectrum antibiotics. In China, the rate of amoxicillin and cotrimoxazole was $79 \%$ of all self-purchasing antibiotics [39] and amoxicillin at 77\% of all self-purchasing antibiotics in Indonesia [47].

Some households used injectable antibiotics in our study. However, these should be used cautiously and can be contraindicated in patients under-five. There are also concerns with the use of chloramphenicol, gentamicin and ceftriaxone. These are the most commonly prescribed parenteral antibiotics for severe respiratory infections [50] in Uganda and can also be obtained over the counter in drug outlets in Uganda [29]. This is a cause for concern

Our findings showed that a common cold with or without a cough appears to be the main driver of self-prescribed antibiotics for ARI among under-fives at households in Kampala (Figure A2). Households are less likely to initiate antibiotics if the common cold and cough (CCC) symptoms present with symptoms of sinusitis, otitis media and pneumonia. This shows that house households are more likely to seek formal health care when the symptoms of the ARI are judged to be severe or of a chronic nature. This correlates with a survey conducted in rural China and developing countries which showed that antibiotics were $42 \%$ more likely to be initiated if the child had a cough and/or common cold [22, 26, 47]. Another survey also showed care givers are $40 \%$ more likely to self-purchase and/or initiate antibiotics in young children if symptoms present with a fever and difficulty in breathing or consult the formal health care system [36]. Other studies in the United States undertaken among prescribers in clinical settings also showed that $44 \%$ of prescribers are likely to initiate antibiotics if ARIs present with symptoms such as Pharyngitis, coughs and common cold $[\mathbf{7}, \mathbf{8}, \mathbf{3 5}]$. The treatment of fevers 
has been over emphasized by community based programmes in Uganda, which may well have influenced household behaviors for the management of ARI $[4,5]$.

Interestingly in our study, household self-prescribing of antibiotics for ARI among under-fives was associated with the location of the household; the level of education of the care taker, prior experience with using antibiotics; and the perceived ability to assess the severity of ARI (Table 3). A study in Trinidad and Tobago, Sudan and Uganda also associated good knowledge on antibiotics and high educations level with self-prescribing of antibiotics $[3,46,52]$ and some authors have linked this practice to the socioeconomic status of the household [25] and access to antibiotics. In a multinational survey on antibiotic treatment among 39 countries, several from Africa depicted poor health seeking behaviors for ARIs among mothers of under-fives that ranged from $41-86 \%$. Seeking care by mothers in Uganda was at 38\% from the public sector [17]. Our study also showed that households living in urban locations have a significantly higher likelihood of treating ARI with antibiotics than rural settings (Table 3). Other studies conducted in Uganda showed that pharmacies, drug shops and clinics dispense whatever medicines the client requests [29]. In Indonesia, the main source of self-purchased antibiotics was from private drug outlets and or leftovers [17,47]. It has been estimated by Mosites et al. [17] that $51 \%$ of cases of acute lower respiratory infections in Uganda are prescribed an antibiotic by physicians. In China, one third of patients/caregivers used left over antibiotics that they obtained them from the health facilities for a second time, mainly to manage fever and breathing problems [22]. In our study, majority (70.5\%) of the caretakers initiate remedies at households for ARI (Table 3); this is higher than findings in Cambodia where only $45 \%$ of care givers initiate therapy with a medicine or other approach at home before seeking health care for fevers/ malaria and majority seek care in the private sector $[\mathbf{1 9}, \mathbf{5 2}]$. Studies have also associated self-prescribing of antibiotics with the level of confidence in assessing the need for an antibiotic in children $[\mathbf{2 2}, \mathbf{4 0}, \mathbf{5 3}]$. This was also seen in to some extent in our study with a lower use of self-prescribed antibiotics among those not confident at self-diagnosis of an ARI (31/ 96). There was also low use of self-prescribed antibiotics among cares confident of selfdiagnosing an ARI (Table 3).

\section{CONCLUSIONS AND RECOMMENDATIONS}

Households in Kampala-Uganda have a high burden of ARIs, particularly the common cold and cough syndrome. Self-prescribing of antibiotics at households for ARI in under-fives is high. As a result, it can be seen that households inappropriately use antibiotics for the management of ARI in children under 5 . This is particularly the case for common colds and cough. Many factors 
drive household use of antibiotics. These include the level of education of the caretaker, confidence in prescribing by parent, left over antibiotics and access to medicines through private drug outlets such as drug shops, clinics and pharmacies.

There is an urgent need for both household and community based interventions and approaches to promote awareness on the safe use of antibiotics in ARI among the under-fives, Caretakers of under-fives should be sensitized of the danger signs of ARI and the consequences of using self-purchased antibiotics for predominantly viral infections. The Government of Uganda should empower and strengthen community drug outlets in the screening and the provision of quality care and treatment for ARI among the under-fives.

Whilst not researched here, there should also be increased access to essential medicines including antibiotics where this is a concern. This can potentially be made feasible through a community based insurance scheme where under-fives can access affordable health care and treatment. Such communities should regularly be supported by a community doctor and/or health worker that follows up the households within a specified catchment area. Studies have demonstrated that communities or patients with a designated family doctor/health worker tend to comply with antibiotics and advice [53].

\section{LIMITATIONS}

The study adopted a crossectional design that collected mainly quantitative data. There could be intrinsic household related factors that drive antibiotic self-purchase for management of ARI among under-fives. Future studies should adopt a qualitative study design to better explain the determinants of antibiotic self-prescribing at households.

\section{Key issues}

- A high incidence of ARI among under-fives is an important driving factor for antibiotic use at households with irrational self-prescribing of antibiotics for under-fives a common practice in Uganda. This is a concern with the overuse of antibiotics a major contributor to antibiotic resistance

Inappropriate antibiotic choices, i.e. the wrong antibiotic, wrong dosage forms and wrong also poses safety concerns among the under-five population

- Broad-spectrum antibiotics of the ATC classes J01C and ATC J01E are the most accessible and used antibiotics, and may aggravate antibiotic resistance

- The porous antibiotic supply chain at the community level enhances unregulated access to antibiotics by households and impact on behaviours for quality care. 
- Educational and other campaigns among key stakeholder groups are essential to reduce inappropriate self-purchasing of antibiotics particularly in children

- Guidelines for use and access to antibiotics at households should be developed. The implementation and regulation of such guidelines should be evaluated

- The need for community based antibiotic stewardship programmes is essential among all stakeholder groups in ambulatory care including community drug outlets

- There is need for an integrated approach to increase access to free and quality health care at a community level particularly for high risk populations such as under-fives

\section{Funding}

This paper was not funded.

\section{Declaration of interest}

The authors have no relevant affiliations or financial involvement with any organization or entity with a financial interest in or financial conflict with the subject matter or materials discussed in the manuscript. This includes employment, consultancies, honoraria, stock ownership or options, expert testimony, grants or patents received or pending, or royalties.

\section{Acknowledgements}

The authors would like to acknowledge Mr. Dennis Mutekanga for leading and coordinating the data collection team. 


\section{REFERENCES}

*Of Importance

1. World Health Organization (2013). Pneumonia Factsheet. Geneva: WHO; 2013. Available from: http://www.who.int/mediacentre/factsheets/fs331/en/

2. Bryce J, Boschi-Pinto C, Shibuya K, Black RE (2005). WHO Child Health Epidemiology Reference Group: WHO estimates of the causes of death in children. Lancet 365:1147-52.

3. Awad A, Eltayeb I, Matowe L, Thalib L (2005). Self-medication with antibiotics and antimalarials in the community of Khartoum State, Sudan. J Pharm Pharmaceut Sci $8(2): 326-331$

4. Källander K, Hildenwall H, Waiswa P, Galiwango E, Peterson S, Pariyo G. (2008). Delayed care seeking for fatal pneumonia in children aged under-five years in Uganda: a case-series study. Bull WHO 2008; 86:332-338.

5. Kallander K, Nsungwa-Sabiti J, Balyeku A, Pariyo G, Tomson G, Peterson S. (2005). Homeand community management of acute respiratory infections in children in eight Ugandan districts. Ann Trop Paediatr; 25:283-291

6. Uganda Bureau of Statistics. (2002). The population and housing census. Entebbe: Uganda Bureau of Statistics,:

http://www.ubos.org/onlinefiles/uploads/ubos/pdf\%20documents/abstracts/Statistical\%20 Abstract\%202002.pdf

7. Acar JF, Kaplan EL, O'Brien TF (1997). Monitoring and management of bacterial resistance to antimicrobial agents: A World Health Organization symposium. Clin Infect Dis 24:S1-S176

8. Gonzales R, Malone DC, Maselli JH, Sande MA (2001). Excessive antibiotic use for acute respiratory infections in the United States. Clin Infect Dis 33:757-762.

9. Laxminarayan R, Matsoso P, Pant S, Brower C, Røttingen JA, Klugman K, Davies S (2016). Access to effective antimicrobials: a worldwide challenge Lancet 387: 168-75

10. Llor $C$ and Bjerrum L (2014). Antimicrobial resistance: risk associated with antibiotic overuse and initiatives to reduce the problem Ther Adv Drug Saf 5(6) 229-241

11. Dyar OJ, Beović B, Vlahović-Palčevski V, Verheij T \& Pulcini C (2016) How can we improve antibiotic prescribing in primary care?, Expert Review of Anti-infective Therapy, 14:4, 403413,

12. Rezal RS, Hassali MA, Alrasheedy AA, Saleem F, Md Yusof FA, Kamal M, Mohd Din R \& Godman B (2015) Prescribing patterns for upper respiratory tract infections: a prescriptionreview of primary care practice in Kedah, Malaysia, and the implications, Expert Review of Anti-infective Therapy, 13:12, 1547-1556,

13. Gabra M, Kisalu A, Hazemba O (2000) Uganda assessment: drug management for childhood illness. Arlington (Virginia): Management Sciences for Health.

14. Schellenberg JA, Victora CG, Mushi A, de Savigny D, Schellenberg D, Mshinda H, Bryce J (2003). Tanzania Integrated Management of Childhood Illness MCE Baseline Household Survey Study Group. Inequities among the very poor: health care for children in rural southern Tanzania. Lancet 361:561-6. 
15. Chandani Y, Noel M, Pomeroy A, Andersson S, Pahl MK, Williams T(2012). Factors Affecting Availability of Essential Medicines among Community Health Workers in Ethiopia, Malawi, and Rwanda: Solving the Last Mile Puzzle. Am J Trop Med Hyg 2012, 87(5 Suppl):120-126.

16. Diaz T, George AS, Rao SR, Bangura PS, Baimba JB, McMahon SA, Kabano A (2013). Healthcare seeking for diarrhoea, malaria and pneumonia among children in four poor rural districts in Sierra Leone in the context of free health care: results of a cross-sectional survey. BMC Public Health 13:1571 - 12,

17. * Mosites EM , Matheson AI, Kern E, Manhart LE, Morris SS and Hawes SE (2014); Careseeking and appropriate treatment for childhood acute respiratory illness: an analysis of Demographic and Health Survey and Multiple Indicators Cluster Survey datasets for highmortality countries. BMC Public Health 2014, 14:446

18. Mendelson M, Røttingen JR, Gopinathan U, Hamer DH, Wertheim H, et al., (2016). Maximising access to achieve appropriate human antimicrobial use in low-income and middle-income countries Lancet 2016; 387: 188-98

19. *Littrell M, Gatakaa G, Evance I, Poyer S, Njogu J, Solomon T et al., (2011). Monitoring fever treatment behaviour and equitable access to effective medicines in the context of initiatives to improve ACT access: baseline results and implications for programming in six African countries. Malaria Journal 2011, 10:327

20. Ntambwe M, Luwombo I, Djurna O: Who sells drugs in rural Zaire? World Health Forum 1994, 15(1):62-63.

21. Lufesi NN, Andrew M, Aursnes I: Deficient supplies of drugs for life threatening diseases in an African community. BMC Health Serv Res 2007, 7:86. Epub 2007/06/19.

22. *Ding L, Sun Q, Sun W, Du Y, Li Y, Bian X, He G, Bai H and Dyar OJ (2015). Antibiotic use in rural China: a cross sectional survey of knowledge, attitudes and self-reported practices among caregivers in Shandong province BMC Infectious Diseases (2015) 15:576

23. Faraha R, Lahoud N, Salameha P, Saleha N (2015). Antibiotic dispensation by Lebanese pharmacists: A comparison of higher andlower socio-economic levels Journal of Infection and Public Health (2015) 8, 37-46

24. Kagoya HR, Kibuule D, Mitonga-Kabwebwe H, Elizabeth Ekirapa-Kiracho E, Ssempebwa JC (2013); Awareness of, responsiveness to and practice of patients' rights at Uganda's national referral hospital. African Journal of Primary Health Care \& Family Medicine; Vol 5, No 1 (2013), 7 pages. doi: 10.4102/phcfm.v5i1.491

25. Vialle-Valentin CE, LeCates RF, Zhang F and Ross-Degnan D (2015). Treatment of Febrile illness with artemisinin combination therapy: prevalence and predictors in five African household surveys Vialle-Valentin et al. Journal of Pharmaceutical Policy and Practice 8:1

26. Tumwikirize WA, Ekwaru PJ, Mohammed K, Ogwal-Okeng JW, Aupont O, Suppl: Management of acute respiratory infections in drug shops and private pharmacies in Uganda: a study of counter attendants' knowledge and reported behaviour. East Afr Med J 2004:S33-S40.

27. Goodman C, Brieger W, and Unwin A, Mills A, Meek S, Greer G: Medicine sellers and malaria treatment in sub-Saharan Africa: what do they do and how can their practice be improved? Am J Trop Med Hyg 2007, 77(6 Suppl):203-218. 
28. Amito Florence $\mathrm{P}$, Otim F, Okongo $\mathrm{F}$, et al. The prevalence and antibiotics susceptibility pattern of Neisseria gonorrhoeae in patients attending OPD clinics at St. Mary's Hospital Lacor Uganda. J Prev Med Hyg. 2012; 53:186-189

29. *Wafula FN, Mirit EN and Goodman CA (2012). Examining characteristics, knowledge and regulatory practices of specialized drug shops in Sub-Saharan Africa: a systematic review of the literature BMC Health Services Research 12:223, 1-18

30. Mukanga $D$, Tiono AB, Anyorigiya $T$, Kallander K, Konate AT, Oduro AR, Tibenderana JK, Amenga-Etego L, Sirima SB, Cousens S, Barnish G, Pagnoni F: Integrated community case management of fever in children under five using rapid diagnostic tests and respiratory rate counting: a multi-country cluster randomized trial. Am J Trop Med Hyg 2012, 87(5 Suppl):21-29

31. *Mukonzo JK, Namuwenge PM, Okure G, et al (2013). Over-the-counter suboptimal dispensing of antibiotics in Uganda. J Multidiscip Healthc. 2013; 6:303-10

32. Seni J, Najjuka CF, Kateete DP, et al. Antibacterial resistance in hospitalized surgical patients: a silently emerging public health concern in Uganda. BMC Res Notes. 2013; 6:298

33. Bebell LM and Muiru AN (2014). Antibiotic use and emerging resistance-how can resourcelimited countries turn the tide? Glob Heart. 2014 September ; 9(3):347-358

34. Kariuki S and Dougan G (2014). Antibacterial resistance in sub-Saharan Africa: an underestimated emergency Acad Sci. 2014 September; 1323(1): 43-55.

35. Nyquist AC, Gonzales R, Steiner JF, Sande MA. Antibiotic prescribing for children with colds, upper respiratory tract infections, and bronchitis. JAMA. 1998;279(11):875-7.

36. Perez F, Hamady B, Dastagire SG, and Altmann M (2009). The role of community health workers in improving child health programmes in Mali. BMC International Health and Human Rights 2009, 9:28 doi:10.1186/1472-698X-9-28

37. Webb C, Ngama M, Ngatia A, Shebbe M, Morpeth S, Mwarumba S, Mwarumba S, Bett A, Nokes DJ, Seale AC, Kazungu S, Munywoki P, Hammitt LL, Scott JA, Berkley JA (2012): Treatment failure among Kenyan children with severe pneumonia-a cohort study. Pediatr Infect Dis J, 31(9):e152-e157.

38. World Health Organisation Improving the containment of antimicrobial resistance WHA; 2005. Available from http://www.searo.who.int/entity/medicines/topics/ wha_58_27.pdf

39. Lee GC, Reveles KR, Attridge RT, Lawson KA, Mansi IA, Lewis IS et al., (2014). Outpatient antibiotic prescribing in the United States: 2000 to 2010 BMC Medicine, 12:96 $1-8$

40. Lee ACC, Chandran A, Herbert HK, Kozuki N, Markell P, Kozuki N, Markell P et al., (2014) Treatment of Infections in Young Infants in Low- and Middle-Income Countries: A Systematic Review and Meta-analysis of Frontline Health Worker Diagnosis and Antibiotic Access. PLoS Med 11(10): e1001741

41. Kish Leslie (1965). Survey Sampling. New York: Wiley available from http://surveyanalysis.org/wiki/Design_Effects_and_Effective_Sample_Size

42. Bennett $S$, Woods T, Liyanage WM, Smith DL: A simplified general method for clustersample surveys of health in developing countries. World Health Stat Q 1991, 44:98-106.

43. Republic of Uganda, Ministry of Health (2014). Annual Health Sector report 2013/2014. Available at http://www.nationalplanningcycles.org/sites/default/files/planning cycle repository/ugan da/final ahspr 2013 2014.pdf 
44. Integrated management of Childhood illnesses - IMCI ()World health organisation ISBN 924 1546441 http://apps.who.int/iris/bitstream/10665/42939/1/9241546441.pdf

45. * Ocan M, Obuku EA, Bwanga F, Akena D, Richard S,Jasper Ogwal-Okeng J and Obua C ( 2015). Household antimicrobial self-medication: a systematic review and meta-analysis of the burden, risk factors and outcomes in developing countries BMC Public Health (2015) $15: 742$

46. Parimi N, LMP Pereira and Prabhakar P. (2004); Caregivers' practices, knowledge and beliefs of antibiotics in paediatric upper respiratory tract infections in Trinidad and Tobago: a crosssectional study. BMC Family Practice 2004, 5:28 doi: 10.1186/1471-2296-5-28,

47. *Widayat A, Suryawati S, Crespigny CD and Hiller JE (2011). Self-medication with antibiotics in Yogyakarta City Indonesia: a cross sectional population-based Survey BMC Research Notes 2011, 4:491

48. Sikolia DN, Mwololo K, Cherop H, Hussein A, Juma M, Kurui J et al., (2002). The Prevalence of acute respiratory infections and the associated risk factors: A Study of children under five years of age in Kibera Lindi Village, Nairobi, Kenya J. Natl. Institute of Public Health, 51 (1) : 2002

49. WHO Collaborating Centre for Drug Statistics Methodology (2014). Guidelines for ATC classification and DDD assignment http://www.whocc.no/filearchive/publications/1 2013guidelines.pdf

50. Republic of Uganda (2012). Uganda Clinical guidelines - National guidelines for managing common conditions http://apps.who.int/medicinedocs/documents/s21741en/s21741en.pdf

51. Republic of Uganda (2008). National Antiretroviral treatment and care guidelines for adultds, adolescents and children http://www.who.int/hiv/amds/uganda moh treatment guidelines.pdf

52. Mukalenge FC, Van der Vennet J, Luboya NO, Vanlerberghe V, Mapatano MA and Criel B (2014). Health-seeking behaviour in the city of Lubumbashi, Democratic Republic of the Congo: results from a cross-sectional household survey. BMC Health Services Research 2014, 14:173

53. Lam TP, Wun YT, Lam KF and Sun KS (2015). Differences in antibiotic use between patients with and without a regular doctor in Hong Kong. BMC Pharmacology and Toxicology (2015) $16: 40$ 
Figures

Figure 1: Household burden of ARIs among the under-fives in Kampala Uganda

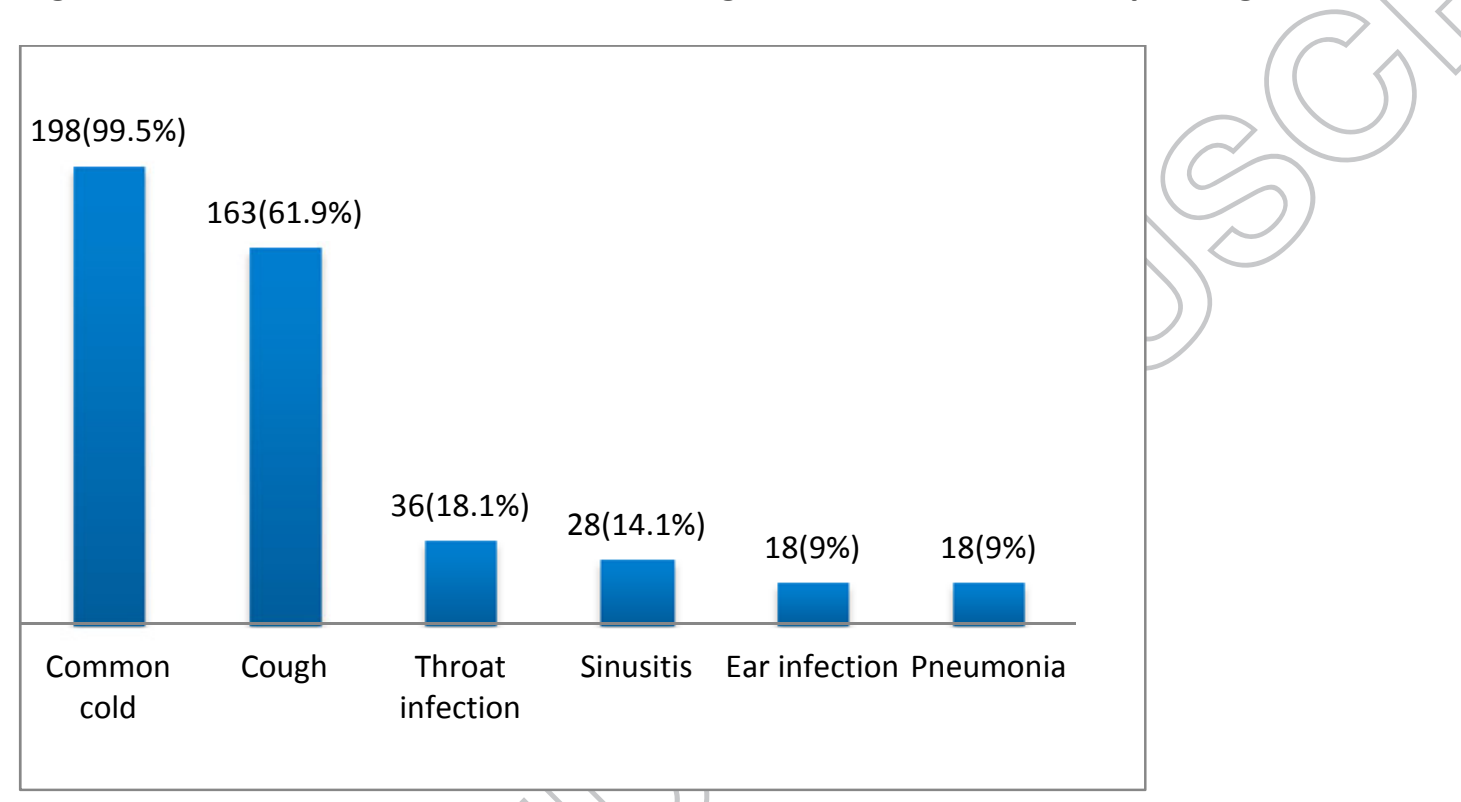


Figure 2: Prevalence of self-medication of under-fives with antibiotics with standard error

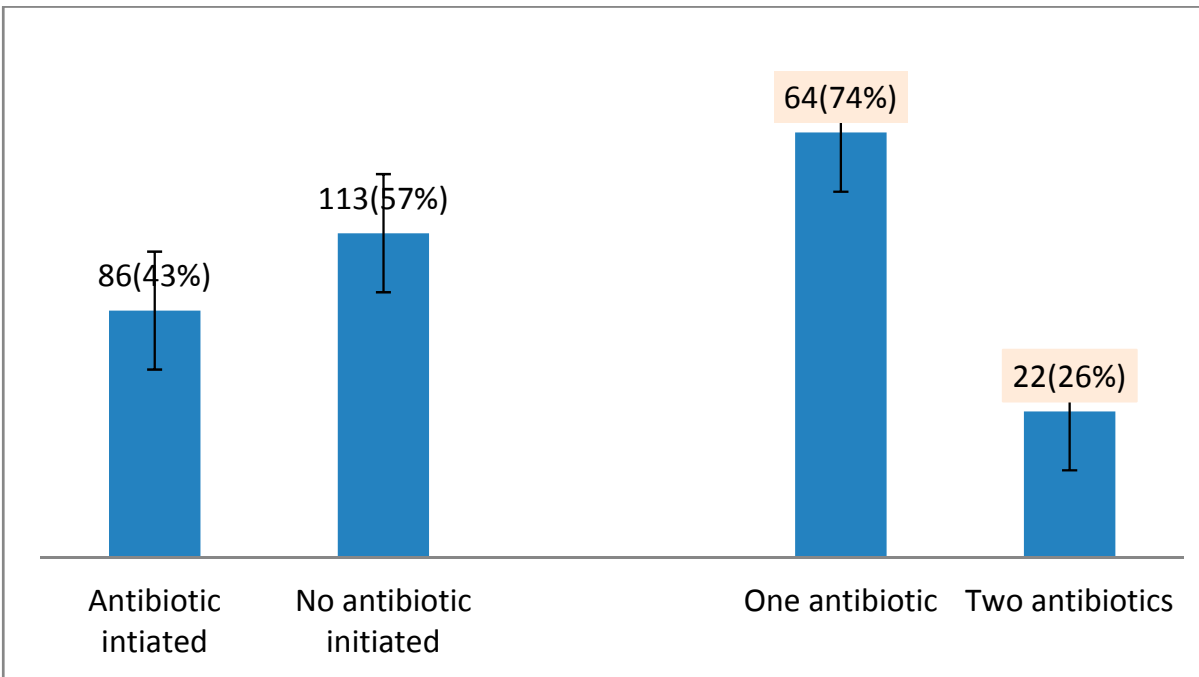

Figure 3: ATC-Classes of antibiotics used in self-medication of ARI in under-fives in Kampala

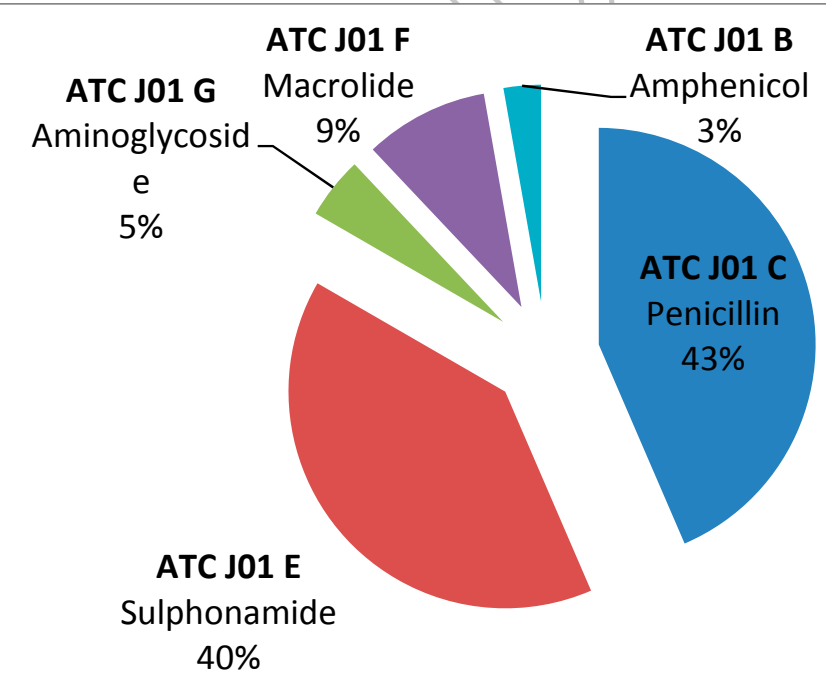




\section{List of tables}

Table 1: WHO recommended treatment of ARI in children*

\begin{tabular}{|c|c|c|}
\hline Symptoms of ARI & Diagnosis & Treatment of choice (WHO IMCl, 2005). \\
\hline $\begin{array}{l}\text { Any general danger sign or } \\
\text { Chest in drawing. Stridor in } \\
\text { calm child. }\end{array}$ & $\begin{array}{l}\text { Severe } \\
\text { Pneumonia } \\
\text { Or Very } \\
\text { Severe } \\
\text { Disease }\end{array}$ & $\begin{array}{l}\text { Give first dose of an appropriate antibiotic. } \\
\text { Refer URGENTLY to hospital }\end{array}$ \\
\hline Fast breathing & Pneumonia & $\begin{array}{l}\text { Give an appropriate oral antibiotic for } 5 \text { days. } \\
\text { PNEUMONIA > Soothe the throat and relieve } \\
\text { the cough with a safe remedy. Advise mother } \\
\text { when to return immediately. Follow-up in } 2 \\
\text { days. }\end{array}$ \\
\hline $\begin{array}{l}\text { No signs of pneumonia or very } \\
\text { severe disease. }\end{array}$ & $\begin{array}{l}\text { No } \\
\text { Pneumonia: } \\
\text { Couch or } \\
\text { Cold }\end{array}$ & $\begin{array}{l}\text { If coughing more than } 30 \text { days, refer for } \\
\text { assessment. } \\
\text { - Soothe the throat and relieve the cough } \\
\text { with a safe remedy. } \\
\text { Advise mother when to return immediately. } \\
\text { Follow-up in } 5 \text { days if not improving }\end{array}$ \\
\hline $\begin{array}{l}\text { Difficulty in swallowing and } \\
\text { inflamed throat }\end{array}$ & & $\begin{array}{l}\text { soothe the throat or relieve a cough, use a safe } \\
\text { remedy }\end{array}$ \\
\hline $\begin{array}{l}\text { Tender swelling behind the } \\
\text { ear. }\end{array}$ & ditis & $\begin{array}{l}\text { Give first dose of an appropriate antibiotic. } \\
\text { Give first dose of paracetamol for pain. } \\
\text { Refer URGENTLY to hospital. }\end{array}$ \\
\hline $\begin{array}{l}\text { Pus is seen draining from the } \\
\text { ear and discharge is reported } \\
\text { for less than } 14 \text { days, } \\
\text { Ear pain. }\end{array}$ & $\begin{array}{l}\text { Acute Ear } \\
\text { Infection }\end{array}$ & $\begin{array}{l}\text { Give an oral antibiotic for } 5 \text { days. } \\
\text { Give paracetamol for pain. } \\
\text { Dry the ear by wicking. } \\
\text { Follow-up in } 5 \text { days. }\end{array}$ \\
\hline $\begin{array}{l}\text { No ear pain and no pus seen } \\
\text { draining from the ear. }\end{array}$ & $\begin{array}{l}\text { No Ear } \\
\text { Infection }\end{array}$ & No additional treatment. \\
\hline
\end{tabular}

*Adopted from the WHO (2005) Integrated management of childhood illnesses 
Table 2: Social demographic characteristics of interviewees at the households $(n=199)$

\begin{tabular}{|c|c|c|c|}
\hline Demographic Characteristic & Frequency (\%) & $\chi^{2}$ & $p$-value \\
\hline \multicolumn{4}{|l|}{ Care taker } \\
\hline Mother & $92(46.2)$ & 42.945 & 0.000 \\
\hline Father & $84(42.2)$ & & \\
\hline Guardian & $23(11.5)$ & & \\
\hline \multicolumn{4}{|l|}{ Sex of respondent } \\
\hline Male & $92(46)$ & 1.280 & 0.258 \\
\hline Female & 108(54) & & \\
\hline \multicolumn{4}{|l|}{ Location of household } \\
\hline Urban & $83(41.5)$ & 29.116 & \\
\hline Rural & $25(12.5)$ & & \\
\hline Semi-urban & $91(45.5)$ & & \\
\hline \multicolumn{4}{|l|}{ Education level } \\
\hline No education & $14(7)$ & & 0.000 \\
\hline Primary & 19(9.5) & & \\
\hline Secondary & $80(40)$ & & \\
\hline Tertiary & $87(43.5)$ & & \\
\hline
\end{tabular}


Table 3: Factors associated with the use of self-prescribed antibiotics

\begin{tabular}{|c|c|c|c|c|}
\hline \multirow[t]{2}{*}{ Characteristic } & \multicolumn{2}{|c|}{ Self-prescribed antibiotic used } & \multirow[t]{2}{*}{$\chi^{2}$} & \multirow[t]{2}{*}{ p-value } \\
\hline & Yes & No & & \\
\hline \multicolumn{5}{|l|}{ Location of household } \\
\hline Rural & 7 & 18 & 6.874 & 0.032 \\
\hline Semi-urban & 34 & 57 & & \\
\hline Urban & 44 & 39 & & \\
\hline \multicolumn{5}{|l|}{ Level of education } \\
\hline No education & 2 & 12 & 15.808 & 0.001 \\
\hline Primary level & 3 & 16 & & \\
\hline Secondary level & 33 & 47 & & \\
\hline Tertiary level & 48 & 39 & & \\
\hline \multicolumn{5}{|l|}{ Confidence to self-diagnose ARI } \\
\hline Not confident(1) & 31 & 65 & & 0.007 \\
\hline Not sure(2) & 52 & & & \\
\hline Confident(3) & 1 & & & \\
\hline Very confident(4) & 2 & & & \\
\hline \multicolumn{5}{|l|}{ ARI treatment behaviour } \\
\hline No treatment initiated & 0 & 1 & 26.068 & 0.000 \\
\hline Homemade remedies & 2 & 14 & & \\
\hline Use herbal medicines & 1 & 14 & & \\
\hline Medicine left overs & & 64 & & \\
\hline Seek medical care & & 21 & & \\
\hline \multicolumn{5}{|l|}{ Antimalarial prescribed } \\
\hline & & 20 & 7.455 & 0.114 \\
\hline & & 94 & & \\
\hline \multicolumn{5}{|l|}{ Non medication therapies used } \\
\hline & 9 & 43 & 24.372 & 0.000 \\
\hline 8 & 77 & 71 & & \\
\hline \multicolumn{5}{|l|}{ Prior ARI appropriately treated } \\
\hline & 3 & 90 & 112.199 & 0.000 \\
\hline$\Delta^{2}$ & 86 & 24 & & \\
\hline \multicolumn{5}{|l|}{ Source of remedies for ARI } \\
\hline Hospital remnants & 4 & 9 & 27.008 & 0.000 \\
\hline Ith center remnants & 1 & 3 & & \\
\hline Clinic (Private) & 37 & 28 & & \\
\hline Pharmacy & 24 & 25 & & \\
\hline Drug Shop & 20 & 23 & & \\
\hline Herbalists & - & 21 & & \\
\hline Open Market & - & 5 & & \\
\hline
\end{tabular}




\section{Appendices}

Figure A1 - Self-prescribed antibiotic regimens for treatment of ARI in under- fives in Kampala

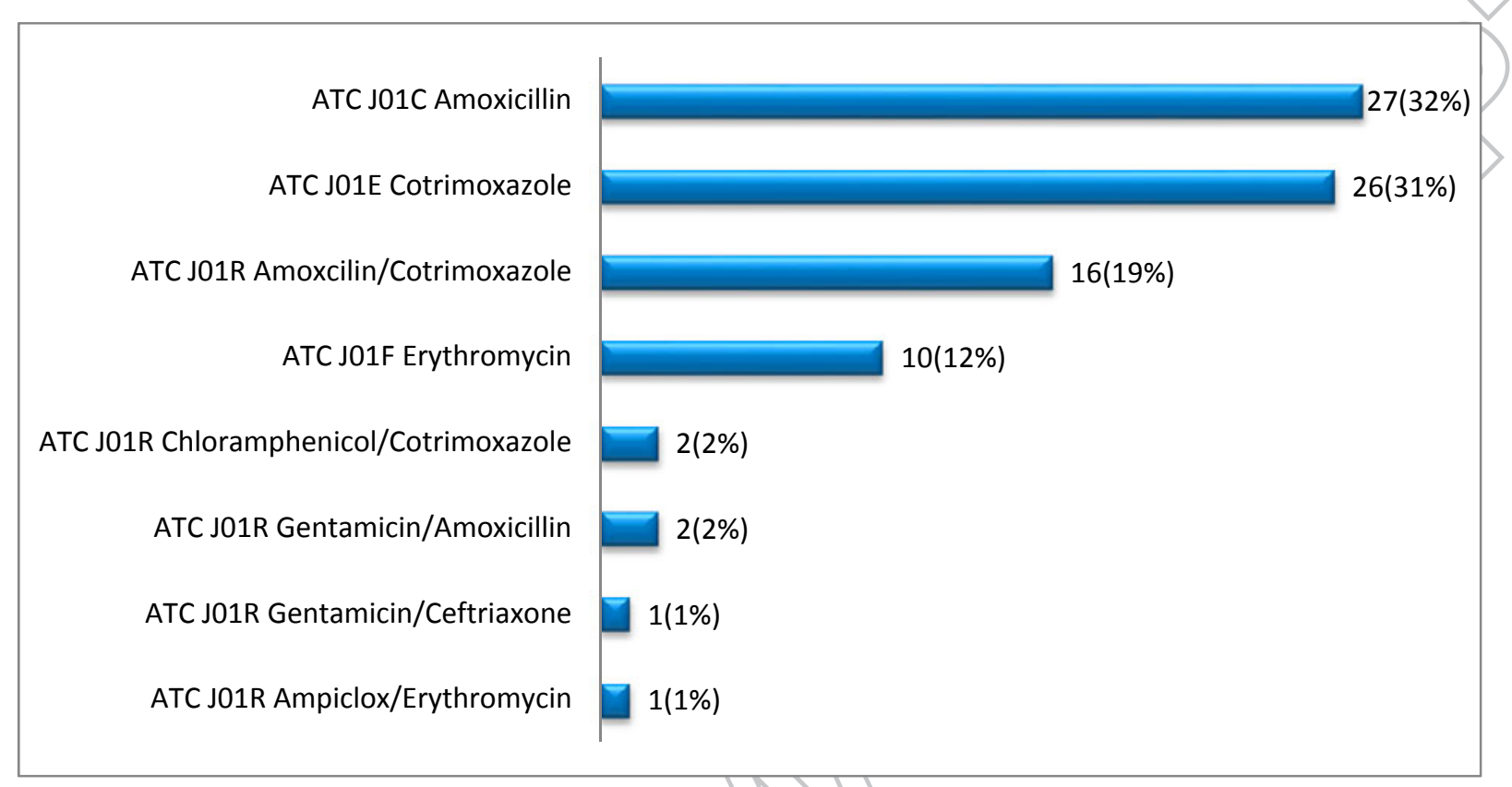


Figure A2: Symptomatic antibiotic self-prescribing for ARI in under-fives in Kampala, Uganda

Common cold, cough \& pneumonia

Common cold, cough, ear infection

Sinusitis

Common cold, sinusitits, cough, ear infection $\$$

Common cold, sinusitits, cough, pneumonia, ear infection

Common cold, sinusitis cough, pneumonia, ear and throat

Cough, pneumonia

Common cold, cough, pneumonia, ear and throat

Common cold, Throat and Ear infection

Common cold, sinusitits, cough, pneumonia

Common cold, Cough, pneumonia/throat infection

Common Cold \& Sinusitis

Common cold, cough, ear and throat

Common cold, Cough, throat infetion

Common cold, Cough \& Sinusitis

Common cold

Common cold \& Cough
Antibiotic used No Antibiotic used 19.

$\Phi$

22

23

25

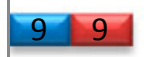

117

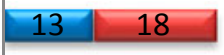

Common cold \& Cough 
Interview guide questionnaire

Title: Assessment of home based Management practices of acute respiratory infections among parents of the $<5$ years children in Kampala, Uganda

\section{Introduction and Purpose:}

Hello. My name is and I would like to ask you a few questions as part of an assessment conducted by one MPH officer, Kagoya Harriet Rachel. The purpose of this exercise is to assess the home based Management practices of acute respiratory infections (ARIs) among parents of the $<5$ years children in Kampala, Uganda.

\section{Consent form}

\section{Procedures:}

I will ask you a few questions about home based management of acute respiratory infections. Your genuine responses will be greatly appreciated. Your participation is absolutely voluntary and there is no penalty for refusing to take part.

\section{Confidentiality:}

If you accept to participate in the interview, I will ask you questions privately without the presence of anyone else and in a place where our discussion cannot be overheard. All information that I record will be kept strictly confidential; your name will not be used and you will not be identified in any way.

\section{Risks/discomfort and Benefits:}

There is no serious risk to you if you agree to participate in this interview activity. Some of the questions may be sensitive for instance, your family information. I want to assure you that all information collected will be kept confidential. This study will help health care givers better understand how parents and other care givers respond to and manage ARI among children below 5 years of age. We will use this information to identify the home based practices for responding to ARIs and identify strategies for improving the management of ARI for children's better health, reduction in morbidity and mortality.

\section{Persons to contact:}

Do you have any questions you would like to ask about the purpose and procedure of this interview? (Take questions if any). I will also be available to take any questions that you may have at the end of this interview.

May I proceed with the interview? Yes No

The interviewer's signature below verifies that informed consent has been verbally obtained Name of Interviewer Sign Date $/ 06 / 2011$ 
Please Contact me for any further questions

Harriet Rachel Kagoya Kibuule

Mobile: +264816873619

Email: kharrietrachel@yahoo.com, h.kagova@sfh.na.org

Dennis Mutekanga

$+256779100383$

Email: mutekangadenis@yahoo.com

Interviewer: Please Tick or fill in the required information as per instruction. Do not read responses unless the directions indicate.

\section{Questions}

\begin{tabular}{|c|c|c|c|}
\hline Serial No. & 101) Date of interview & $\begin{array}{l}\text { 102) Division } \\
\text { (1) } \square \text { Nakawa } \\
\text { (2) } \square \text { Kawempe } \\
\text { (3) } \square \text { Rubaga } \\
\text { (4) } \square \text { Kampala central } \\
\text { (5) } \square \text { Makindye }\end{array}$ & $\begin{array}{l}\text { 103) Initials of data } \\
\text { Collector's name: }\end{array}$ \\
\hline $\begin{array}{l}\text { Family \& respondent } \\
\text { Demographics }\end{array}$ & $\begin{array}{l}\text { 104). Role of } \\
\text { Respondent } \\
\text { (1) } \square \text { Mother (2) } \square \\
\text { Father } \\
(3) \square \text { Other specify } \\
\end{array}$ & $\begin{array}{l}\text { 105).Sex of } \\
\text { Respondent } \\
\text { (1) } \square \text { Male (2) } \square \text { Female }\end{array}$ & $\begin{array}{r}\text { 106). Age of } \\
\text { respondent: } \\
\text { years }\end{array}$ \\
\hline
\end{tabular}




\begin{tabular}{|c|c|c|c|}
\hline & $\begin{array}{l}\text { 107). Residence of } \\
\text { respondent } \\
\text { (1) } \square \text { Urban } \\
\text { (2) } \square \text { Rural } \\
\text { (3) } \square \text { Semi-urban }\end{array}$ & $\begin{array}{l}\text { 108). Respondent's } \\
\text { highest level of } \\
\text { education } \\
(1) \square \text { No education } \\
(2) \square \text { Primary education } \\
(3) \square \text { Secondary } \\
\text { education } \\
\text { (4) } \square \text { Tertiary education }\end{array}$ & $\begin{array}{l}\text { 109). Respondent's } \\
\text { employment status } \\
\text { (1) } \square \text { Formal } \\
\text { employment } \\
\text { (2) } \square \text { Casual } \\
\text { employment } \\
\text { (3) } \square \text { Self employed } \\
\text { (4) } \square \text { Unemployed }\end{array}$ \\
\hline & $\begin{array}{l}\text { 110). Family Size: } \\
\text { Total } \\
\text { Adults } \\
\text { Children }\end{array}$ & $\begin{array}{l}\text { 111). Number of } \\
\text { children (1)< } \\
3 \text { months: } \\
\text { (2) } 4-12 \\
\text { months: } \\
\text { (3) } 1-3 \text { years: } \\
\text { (4) } 3-5 \text { years: }\end{array}$ & $\begin{array}{l}\text { 112). How many of }<5 \\
\text { yrs have completed } \\
\text { immunization? }\end{array}$ \\
\hline $\begin{array}{l}\text { 113). Are children of } \\
\text { school going age } \\
\text { Schooling? } \\
\text { (1) } \square \text { YES } \\
\text { (2) } \square \text { NO }\end{array}$ & $\begin{array}{l}\text { 114). If Yes, state } \\
\text { Number of Children }< \\
5 \text { years going to School } \\
\text { kids }\end{array}$ & $\begin{array}{l}\text { 115). Type of School } \\
\text { (1) } \square \text { Public } \\
\text { (2) } \square \text { Private } \\
\text { (3) } \square \text { Both Private \& } \\
\text { Public }\end{array}$ & $\begin{array}{l}\text { 116). Location of } \\
\text { School } \\
\text { (1) } \square \text { Urban (2) } \square \\
\text { Rural } \\
(3) \square \text { Semi-urban }\end{array}$ \\
\hline $\begin{array}{l}\text { 117). Have any of your } \\
\text { children < } \mathbf{5} \text { years } \\
\text { suffered from ARI? } \\
\text { (Explain what ARIs are } \\
\text { and give all the } \\
\text { symptoms) } \\
\text { (1) } 9 \text { Yes } \\
\text { (2) } \square \text { No } \\
\text { (3) } \square \text { I don't know }\end{array}$ & $\begin{array}{l}\text { Symptoms of ARI } \\
>\text { Flu/ Common cold } \\
>\text { Ear infections } \\
>\text { Nose Congestion } \\
>\text { Throat infections } \\
>\text { Cough infections } \\
>\text { Breathing Sounds } \\
>\text { Breathing fast } \\
>\text { Others }\end{array}$ & $\begin{array}{l}\text { 118). Type of ARI } \\
\text { suffered } \\
\text { (1) } \square \text { Common Cold } \\
\text { (2) } \square \text { Sinusitis } \\
(3) \square \text { Flu } \\
\text { (4) } \square \text { Cough } \\
(5) \square \text { Pneumonia } \\
(6) \square \text { Ear infections }\end{array}$ & $\begin{array}{l}\text { 119). When did they / } \\
\text { she/he (kids }<\mathbf{5} \text { yrs) } \\
\text { last suffer from ARI? } \\
\\
\text { 1) } \square 0-2 \text { weeks ago } \\
\text { 2) } \square 2-4 \text { weeks ago } \\
\text { 3) } \square>4 \text { weeks ago } \\
\text { 4) I don't remember }\end{array}$ \\
\hline
\end{tabular}




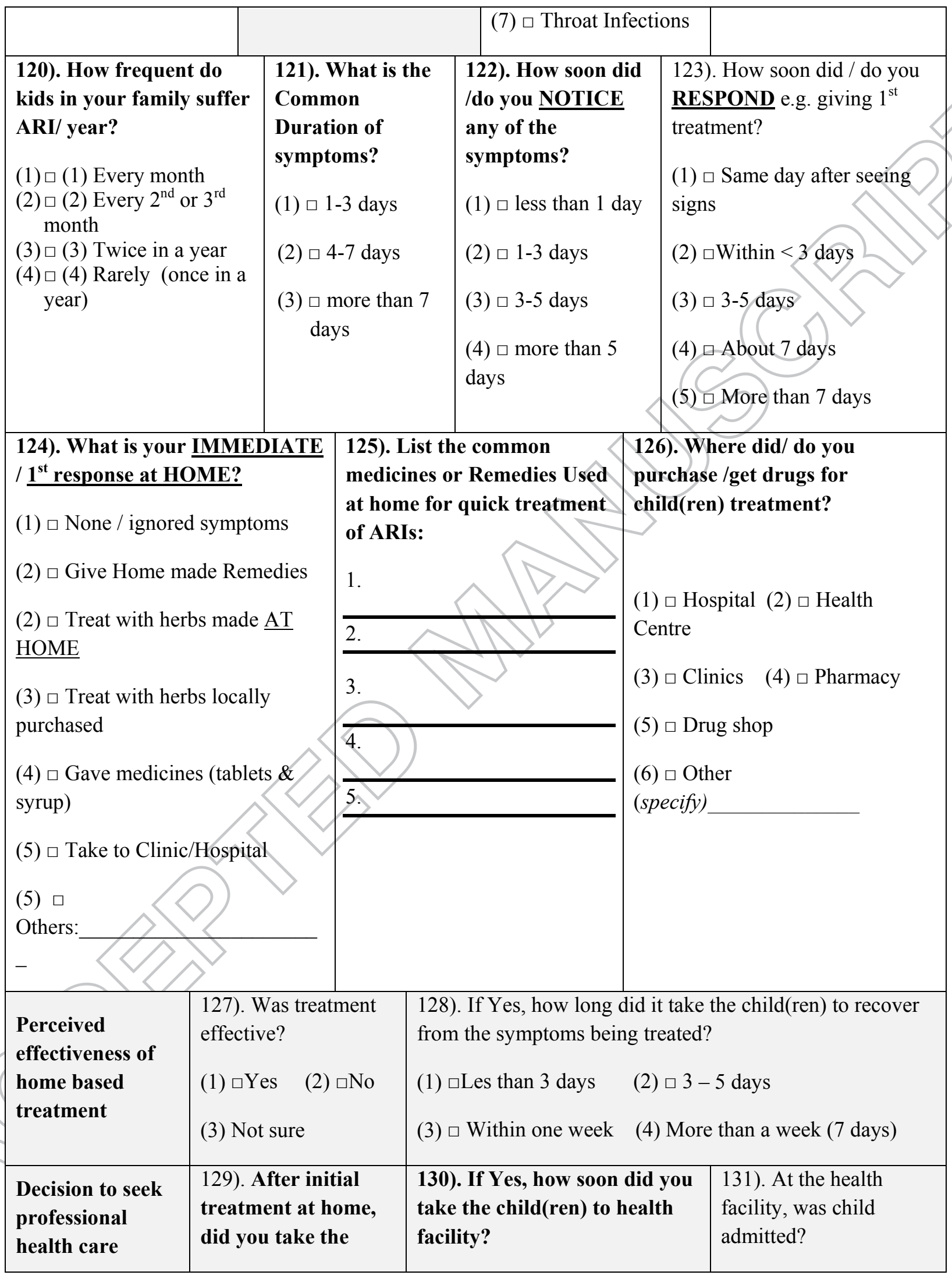


services

child(ren) to a health
facility?
$\begin{array}{ll}(1) \square \text { Yes } & \text { (2) } \square \text { No }\end{array}$

(1) $\square$ Same day after giving initial treatment

(2) $\square$ Within 3 days (3) $\square$ 3-5 days

(4) $\square$ After one week (7 days)
(1) $\square$ Yes (2) $\square$ No

(3) $\square$ Don’t remember

132). How confident do you feel when managing the last ARI episode?

(1) $\square$ Not confident (2) $\square$ Not sure (3) $\square$ Somewhat confident (4) Very confident

133). What would you have done differently if the symptoms re-occur?

1.

2 .

3.

135). What would you recommend the government or ministry of health should do to improve home based management of ARIs?

1.

2.

3.

136). What determines that you will take the child to hospital or not?

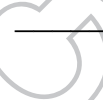

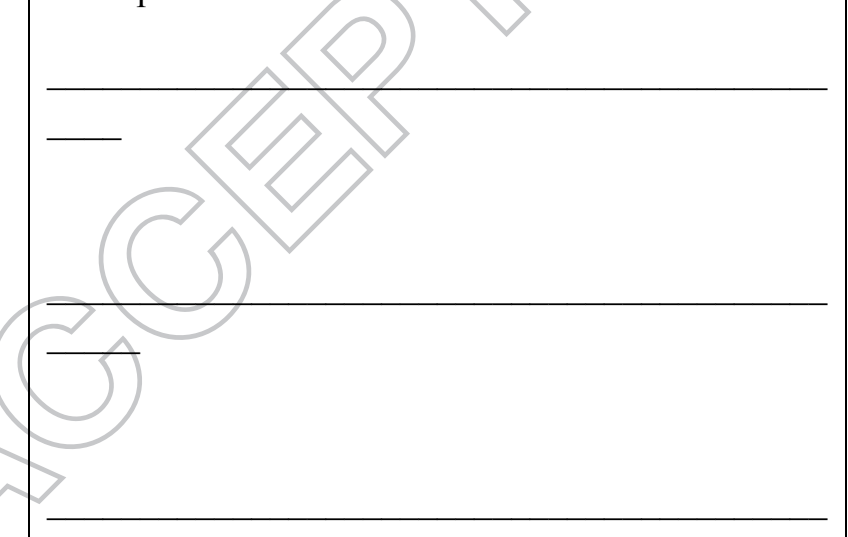

137). How do you tell that the child is severely ill and needs to be taken to Hospital
134). Do you feel you have the necessary knowledge and skill to

handle ARI at home?

(1) $\square$ Yes (2) $\square$ No

(3) $\square$ Not sure 


\section{Thank you very much for your participation!}

Reminder to interviewer: check that all questions are responded to. 